\title{
予後から見た直腸肚門癌手術々式の選択について
}

\author{
東邦大学第 1 外科教室 \\ 粕川 剛義
}

\section{THE OPERATION METHODS FOR ANORECTAL CANCER CONSIDERING FROM FOLLOW UP STUDIES}

\section{Takeyoshi KASUKAWA, M.D.}

Ist Department of Surgery, Tohō University, School of Medicine, Tokyo

索引用語 直腸癌の予後, 相対生存率, 選択的下腸間膜動脈撮影, 直腸早期癌, 前方切除術の適応.

1.はじめに

直腸肛門癌手術々式の主流は腹会陰式直腸切断術であ る.この術式は根治性に富んではいるが, 常に人工肛門 を伴らために，患者の精神的括よび肉体的菬痛は計り知 れないるのがある.そこで病変部の進行度と部位によ り，根治珄を損わずに肛門括約筋を温存し，人工肛門の 造設を避子る術式が種々検討されてきた。しかし，根治 性と機能保存とは相反する面が多く, 術式の選択にはと くに慎重を期さなければならない、今回は，主に予後の 面から直腸肛門癌手術々式の選択について㭘討し, また Retrospectiveな検討により，術式選択に当り考慮す心゙ きであろらと思われる点について述べてみたい。

\section{2. 症例について}

東邦大学第 1 外科教室では，1952年より1976年12月 までに直腸肛門癌322例 (primary cases) を経験してお ク，これらの症例について検討した．術式の内訳は表 ! の如くである. 括約筋温存術式は62例 $19.25 \%$ で，それ 程多いものではなかった。腹会陰式直腸切断術は189例 $58.7 \%$ で半数以上を占めている. しかし，人工肛門造設 術のみの症例を含めた非切除例が70例 $21.7 \%$ あった。 治癒切除率をみると, 前方切除術では根治性のない症例 にも行っているために，80\%と引き抜法よりは良くなか った．腹会陰式直腸切断術は61.4\%で，それ程高いる。 ではなかった。本術式の治癒切除率を高めるには，今後 一周の努力が必要である.すなから, 癌の早期発見と積

\footnotetext{
*第10回日消外総会シンポ I
} 直腸癌切除手術術式の選択

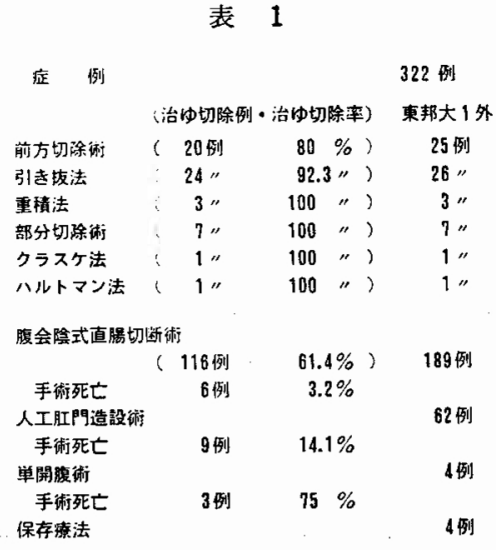

極的な搪大根治手術の採用であろら．われわれの症例は 24年間の follow up のため, 古い症例は現在行われて いるよらな払大根治手術が施行されて扣らず，そのため に多少治癒切除率が低下している. 手術死亡は術後 1 力 月以内に死亡した症例とした. 括約筋温存術式では手術 死亡例はなく，腹会陰式直腸切断術では $3.2 \%$ あった。

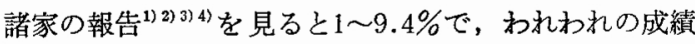
はほぼ満足するものであった。しかし，癌性腹膜炎，切 除不能や遠隔転移を伴う未期癌患者などで人工肛門造設 術のみに終ったるのや，単開腹術のみの患者の死亡率は 高かった。

\section{3. 術前検查のチェックポイント}

術前諸検查で低蛋白血症，脱水および貧血などがあれ ば，その改善は当然であるが，とくに選択的下腸間膜動 脈撮影は術式の選定に，重要な意義を持つるのと考兄ら 
表 2 術後腸管穿孔・噮死症例:

\begin{tabular}{|c|c|c|c|c|}
\hline \multirow{3}{*}{ 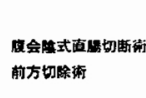 } & \multicolumn{2}{|r|}{ 発生碩度 } & \multicolumn{2}{|c|}{ 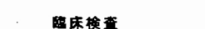 } \\
\hline & 20 & $1.1 \%$ & 整白 & 正㗬（全例) \\
\hline & 409 & $.13 .8 \%$ & 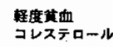 & 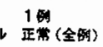 \\
\hline 引引㐘报法 & 169 & $3.7 \%$ & & 正萧 (全列) \\
\hline 早被法 & 2例 & $40.0 \%$ & 经度肝雫 & 1的 \\
\hline st & 969 & & & 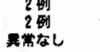 \\
\hline
\end{tabular}

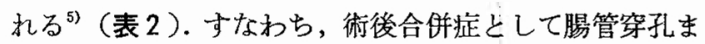
たは壊死を伴った症例を Retrospective に検討したとこ ろ, 臨朱検查での異常は軽度肝障害 1 例, 高血圧症 2 例 および梅毒 2 例であった。しかし，これらの障害がただ らに穿孔，壊死に結びつくものとは考えられず，そこで 選択的下晹間膜動脈撮影写真を検討した．9例中 2 例は 施行せず，3 例はカテーテルの挿入失敗例で，4例中 3 例 $(75 \%)$ に Marginal artery に動脈硬化症を認めた。 これは残存結腸の血流障害を若起し, 術後の腸管穿孔ま たは壤死の直接原因になるものと思われるため，このよ うな症例に括約筋温存術式を採用することは避けるべき であると考光ている。

表 3. Two stage に手術を行つた症例

\begin{tabular}{|c|c|c|c|}
\hline 1. & 江門造設 & 腹会陰式直腸切断術 & 10 例 \\
\hline 2. & . & 引き抜法 & $1 "$ \\
\hline 3. & " & 前方切除術 & $1 "$ \\
\hline
\end{tabular}

$\begin{array}{ll}\text { 理 由 } & \\ \text { 1. 全身状態が悪い } & 7 \text { 例 } \\ \text { 2. 高度使秘のため } & 4 " \\ \text { 3. 術中出血のため } & 1 "\end{array}$

術前の患者の状態により，Two stage に根治手術を行 った方が良い場合があることを念頭に㯰くべきである 5. Two stage に根治手術を行った症例は12例あるが, その理由は表3の如くである。まず，人工肛門を造設 し, 次に病変の状態により術式を選定し根治手術を行う わけであるが，Two stage operation でも括約筋温存術 式が可能であることがわかる。

\section{4. 各術式と予後の関係}

1) 生存率の計算について

生存率の計算は慎重に行わねばならない,とくに最近 の上5に, 種々の治療群の比較や腫瘍の進行度別群の比 較などを行う場合に，そのデータ処理はもっと理想的な 方法で一定したるのでなければならない，従来の方法 （消息不明例を含めてこれを死亡例とみなした生存率と， これを除いた生存率とを出し，あわせて消息不明率を明 記与る. 5 年生存率 : 5 年以上生存例 $/ 15$ 年以上経過症例
数×100）では数々の不合理な点がある。その代表的な ものは他病死と消息不明者の取扱い拉よび各患者の平均 余命が異なることである。ここでは詳細については触れ ないが，他論文78) 9)を参考にしていただきたい，著者は 生命表に基づく相詨生存率が; 現在のところもっとも理 想的な生存率の表現方法であると考えており，この方法 にしたがった。すなわち，昭和39年以前に手術を施行し た患者については栗原・高野ら”の期待生存率表を用 い，40４5年までの症例については小池・田代たち ${ }^{8)}$ コホート生存率表を使用した，45～50年の症例について は，著者が簡易生命表を用いて，期待生存率を作成して 相対生存を求めた。また50年の期待生存率表は55年まで 流用した。（注 : 50 歳女48年手術例の 5 生率は表から求 められるが，10生率は58年で60歳となるため算出不能と なり，この場合は 7 生率55年57歳まで算出し，8生率以 後は空白としそのままで期待生存率の平均值を求めた).

\section{5. 各術式別および m. sm 癌の生存率について}

1) $\mathrm{m} \cdot \mathrm{sm}$ 癌症例について

深達度 sm までの症例はすでに示した ${ }^{5)}$ 通りであり， 15例と少ないが， $m$ 癌の 7 例に部分切除術を施行し, 4 年以上 13 年間の follow up で再発死亡例は認められて いない，しかし，6例の sm 癌ではすべて根治手術を施 行しているが，1例に癌死を認め 1 例に再発が疑われて いる.15例中 5 例の死亡を認めているがこれらの症例 の予後を計算したものが表 4，5 で梁る。実測生存率 (observed) は 5 年 : 70.7\%，10年 : 61.4\%であるが， この群は比較的高齢者が多く（87歳11年生存中，83歳 5 年 9 カ月死亡 および 87 歳 6 年生存中など), 相対生存率

$$
\text { 表 } 4
$$

\begin{tabular}{|c|c|c|c|c|c|c|c|c|c|c|}
\hline & \multicolumn{7}{|c|}{ Early Cancer Group } & \multicolumn{3}{|c|}{ Survival Rate } \\
\hline & $1 x$ & $d x$ & $u x$ & $\kappa x$ & $1 ' x$ & & $\mathrm{px}$ & observed & expected & relative \\
\hline & 15 & - & - & - & 15 & 0.000 & 1.000 & 1.000 & & 1.029 \\
\hline$-c$ & 15 & - & - & - & 15 & 0.000 & 1.000 & 1.000 & 0.939 & 9.074 \\
\hline - & 15 & 1 & - & - & 15. & 0.067 & 0.933 & 0.933 & 0.898 & 1.039 \\
\hline 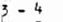 & 14 & 1 & - & 1 & 13.5 & 0.074 & 0.926 & 0.864 & 0.865 & 0.999 \\
\hline & 12 & 2 & - & 2 & 11 & 0.182 & 0.818 & 0.707 & 0.830 & 0.852 \\
\hline & 8 & 1 & - & - & 8 & 0.125 & 0.875 & 0.674 & 0.773 & 0.794 \\
\hline & 7 & - & - & 1 & 6.5 & 0.000 & 0.875 & 0.614 & 0.747 & 0.822 \\
\hline & 6 & - & - & 1 & 5.5 & 0.000 & 0.875 & 0.614 & 0.723 & 0.849 \\
\hline & & - & - & 1 & 4.5 & 0.000 & 0.875 & 0.614 & 0.644 & 0.953 \\
\hline & 4 & - & - & 1 & 3.5 & 0.000 & 0.875 & 0.614 & 0.579 & 1.060 \\
\hline & 3 & & & 3 & & & & & & \\
\hline
\end{tabular}

(relative)は 5 年 : 85.20\%，10年：106\%であった。 すなわち，10年間の follow up ではこの群と同一の正常 者群とを比較すると, 生存率ではより良好であることが わかり，治療方針に愦りのないことが裏づけられてい る.すでに述べてきた通り，われわれの治療方針》10111 は， m 癌は部分切除術 (partial resection or endoscopic polypectomy) を行い，sm癌は根治手術を行うというも 


\section{表 5 各術式と予後の関保（相対生存率）}

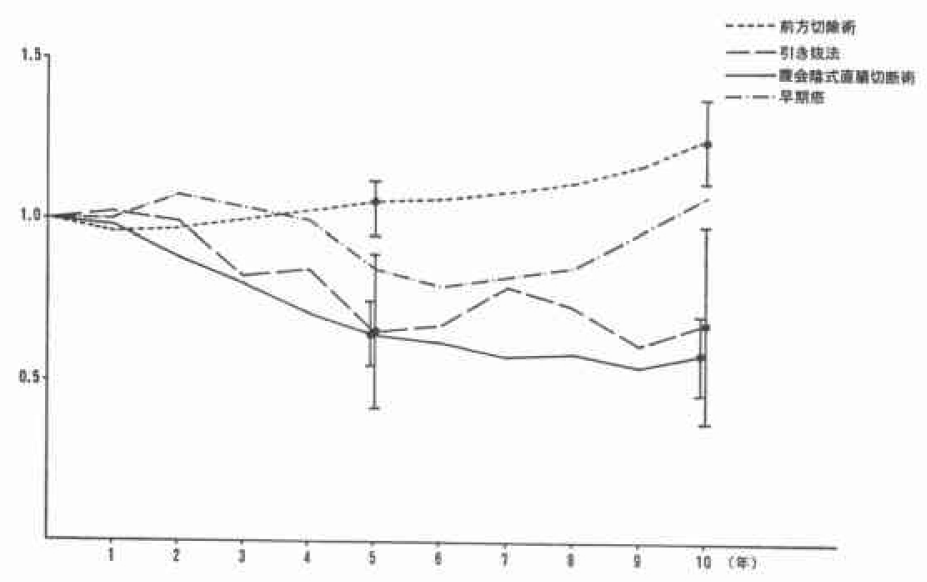

表 6

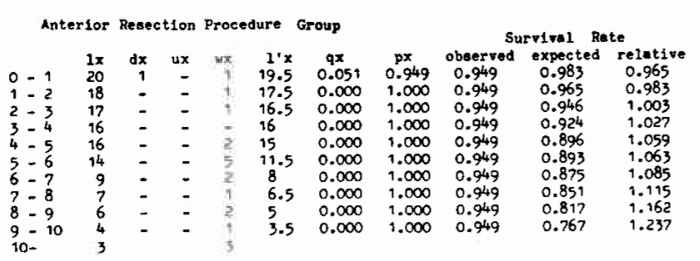

のである.

2）前方切除術について

治瘾切除を行った20例中 1 例の消息不明があったが， 数度に亘る調査の結果死亡が推定されたために，死亡例 として取扱かった。1 例（59歳男子）に術後 5 年目に局 所再発（単開腹術に終った）を誌めているが現在生存中 である. 生存率は表 5, 6亿示す通り実測で 5 および10 年 : $94.9 \%$, 相対で 5 年 : $105.9 \%, 10$ 年 : $123.7 \%$ あ り,この群の生存率は非常に良く満足するものであり， 術式選択が正しいものと思われた。

3）引き拉法

24例に治癒切除を行っているか゚ 5 年以下の死亡例が 10 例あり，その予後は表 $5 ， 7$ に示す通りである．実測

$$
\text { 表 } 7
$$

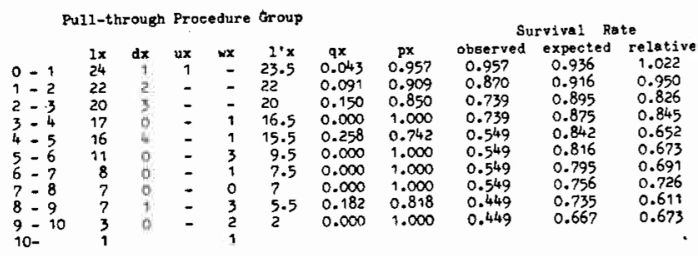

表 8

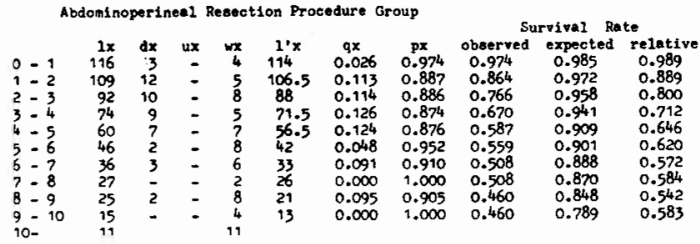

生存率は 5 年 : $54.9 \%, 10$ 年 : $44.9 \%$, 相対生存率 は 5 年: $65.2 \% ， 10$ 年: $67.3 \%$ であり, 前二者に比して 予後は覀く, 術式適応の再検討が必要であると思われ た。

4）腹会陰式直腸切断術

116例に治疹切除術を行っているが, その予後は表 5 , 8 の如くである。実測生存率は 5 年 : $58.7 \% ， 10$ 年46 $\%$, 相対生存率は 5 年 : $64.6 \%, 10$ 年 : $58.3 \%$ であり, 引き拔法と同様に満足すべき結果ではなかった，その原 因については明快な解答が出ていないが，後に二・三検 討した。

以上の様に生存率から各術式の結果をみたが, それら の適応についてさらに検討を加えた。

\section{5. 各術式における窝脂の高さと進行度の関係}

各術式の適応を癌腫の高さと進行度を基準にして Retrospective に見たものであり，今後の適応確立に役立 つものと考えた.

1) 前方切除術

この群の予後は非常に良く満足するものであった．そ れではどのような症例に本術式が行われているかを見 たのが表9である.すなわち, stage Iの症例では肛門 
表 9 前方切除術・高さと進行度の関係

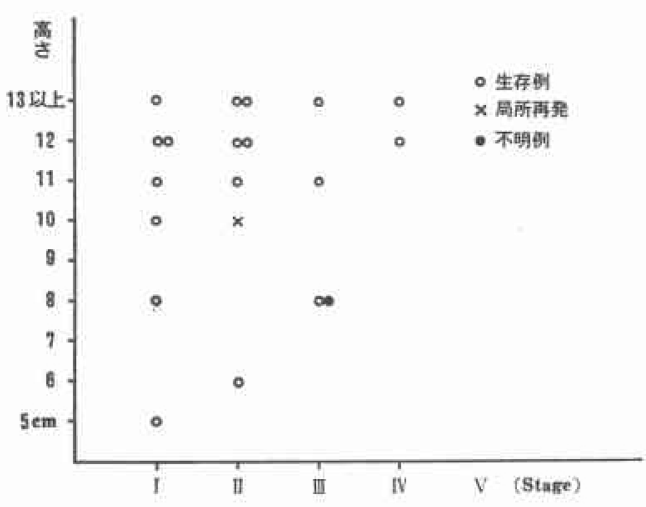

表10 引き技法・高さと進行度の関係

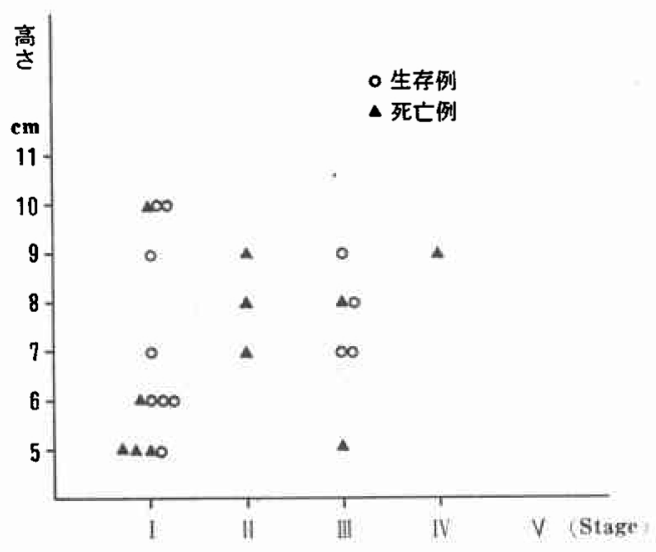

表12 腹会陰式直晹切断術症例の進行度, 高さ の頻度と予後

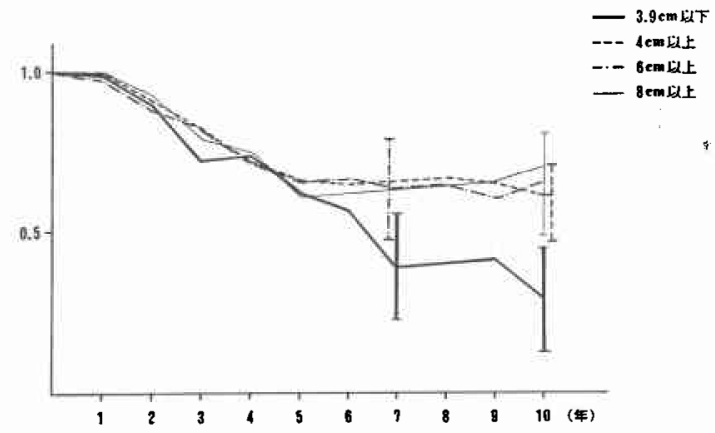

緑より癌腫の下縁が $5 \mathrm{~cm}$ までの あのに可能であり， stage II の症例では $6 \mathrm{~cm}$, stage IIIの症例では $8 \mathrm{~cm}$ および stage IVの症例では $12 \mathrm{~cm}$ までの症例に前方切除術が行 われている.これは癌腫の高さと進行度を考慮して術式 を選んできたわれわれの方針が正しいものであったもの と思われる。

2)引き抜法

しかし，本法に和いては癌腫の高さと進行度の間に は，特別な関係がみられなかった表10. 各 stage と種 々の高さの症例に死亡例がみられて特り, 今後さらに適 応の再検之他再発因子の検討が必要であると思われた。

3）腹会陰式直腸切断術

この群の進行度および高さと予後の関係を表11に示し た. 各 stage の左が肛門縁より腫瘍の下縁が4cm 以下 の症例で, 右が $8 \mathrm{~cm}$ 以上の症例である. 非治瘾妇除例

表11癌腫の高さと予後の関係（相対生存率）

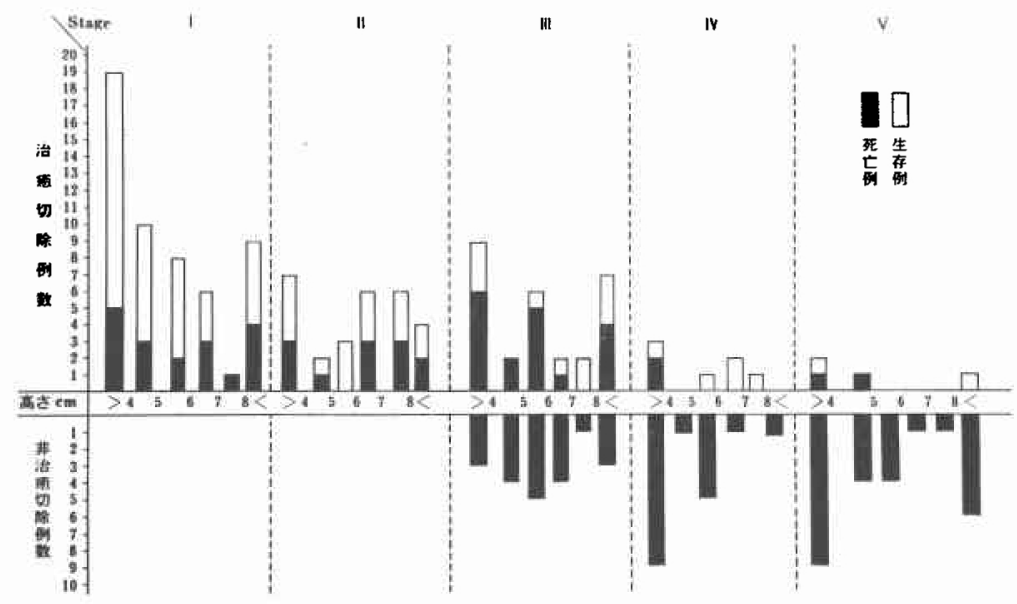


は stage II以下に認められ全例死亡している. stage と 予後の関保を見ると、I II IIIまでは略平行しているが， IVKおいては非常に良く，V650\%と比較的良かった。 なお，この stage と予後の関係については，都者が第77

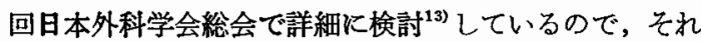
を参照していただきたい，ここではさらに，畽場の高さ と予後の関係について検討した表12.

高さに上る検討は $3.9 \mathrm{~cm}$ 以下， $4 \mathrm{~cm}$ 以上, $6 \mathrm{~cm}$ 以上 および8cm 以上の 4 群にわけて，相対生存率で行った。 5 年までは 4 群に著明な差はみられず， 7 年以後で 3.9 cm 以下の群に低下がみられ10年まで続いている。そこ で 7 生率以後について，他群之の有意差を検討するため に，95\%信頼区間に㧍りる標準誤差を求めた。7生率で は他群之有意差はなく，10生率に打いて有意差を認め た.すなわち、この症例の多くは標準的手術であるた め，この結果を見る限りでは，少なくとも肚門部癌 (3.9 cm以下) 飞昖大根治手術が絶対に必要であると考 壳られた。

\section{7. 術後死亡例の検討}

著者たちは毎年住民票むたはそれに準ずる戸籍薄およ び外来で，術後の follow upを行っているが，死亡時の 状態を全例確認することはできない，61例の内訳を表13 に示したが，再発例拉よび他疾患死亡例は全例当科で它 の病変を確認したすのである．气の再発形成は表14 亿示 した通りである! 局所再発と癌性腹膜炎の症例は局所々 腹膜炎の項目にそれぞれ入れてある。ただし，局所再発 に伴う周柬限局性の癌性腹膜炎は局所のみとした，腹会 陰式直腸切断術に扣いてはやはり局所再発が多く，1例 に人工肛門部の再発も認めている。この症例は教室の䤵 田たち ${ }^{14)}$ む述べているように，管内転移によるものと考 えられた。 stage との関係をみると各 stage に再発例が
表13 治嘴切除死亡例の検討

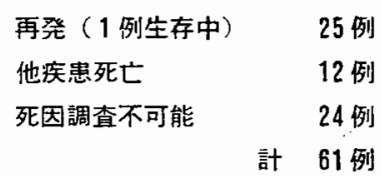

$\begin{array}{ll}\text { 他疾患死亡の原因 } & \\ \text { 手術死亡（非癌疾患） } & 4 \text { 例 } \\ \text { 肝炎 } & 2 \text { 例 } \\ \text { 老衰 } & 2 \text { 例 } \\ \text { 胃癌 } & 1 \text { 例 } \\ \text { マイトマイシン中毒 } & 1 \text { 例 } \\ \text { 肺炎 } & 1 \text { 例 } \\ \text { レントゲン大腸炎 } & 1 \text { 例 }\end{array}$

みられ，I・IIになくIV・Vに多いといらことはなかっ た。しかし，前回の検討による ${ }^{15)}$ と，再発例の stage と 再発期間には統計学的（5\%危険率に和ける $\mathrm{t}$ 検定）に 有意の差をるって再発期間が短かくなっていた， stage I : 71 カ月, stage II $: 48$ カ月, stage III $: 27$ カ月, stage IV : 19カ月であった.

括約筋温存術式の症例に㨟いても，局所，肝拉よび肺 に再発がみられるが，症例が少ないために，その特性に ついては論じられなかっだ。

\section{8. 考察および総括}

$\mathrm{m} \cdot \mathrm{sm}$ 癌症例について: 現段階に和ける $\mathrm{m}$ 癌の治療 方針く部分切除術〉にはすず問題のないところであろ う. しかし，sm 癌については大別して2つの考方方が ある，1）sm 癌は根治手術が必要である，2）sm 癌 には部分切除術を行い，術後綮重な fallow up を行う。 まず1)の著者たちの症例は前述した通り，4年以上 13 年 間の follow up で 1 例の癌死を認めていることである.

表14 再発形式

\begin{tabular}{|c|c|c|c|c|c|c|c|c|}
\hline & 症 例 & 局 所 & 腹膜资 & 肝 & 肺 & 骨・骨髄 & 人工肛門部 & \\
\hline 腹会陰式直腸切断術 & 20 例 & $13(65.0)$ & $11(55.0)$ & $10(50)$ & $8(40.0)$ & $5(25.0)$ & $1(5.0)$ & $\begin{array}{r}\text { Stage I } 4 \text { 例 }(20) \\
\text { II } 8 \text { 例 }(40) \\
\text { III } 4 \text { 例 }(20) \\
\text { IV } 2 \text { 例 }(10) \\
\text { V } 2 \text { 例 }(10)\end{array}$ \\
\hline $\begin{array}{l}\text { 引き抜法 } \\
\text { 重皘法 } \\
\text { 前方切除術 } \\
\text { (生存中) }\end{array}$ & $\begin{array}{l}3 \text { 例 } \\
1 \text { 例 } \\
1 \text { 例 }\end{array}$ & $\stackrel{1}{(-)}$ & $\begin{array}{l}(-) \\
(-)\end{array}$ & $\frac{(-)}{1}$ & $\begin{array}{l}2 \\
1\end{array}$ & $\begin{array}{l}(-) \\
(-)\end{array}$ & $=$ & $\begin{aligned} & \text { Stage I } 0 \text { 例 } \\
& \text { II } 3 \text { 例 }(60) \\
& \text { UI } 1 \text { 例 }(20) \\
& \text { IV } 1 \text { 例 }(20) \\
& \text { V } 0 \text { 例 }\end{aligned}$ \\
\hline
\end{tabular}


この症例は部分切除を行い，sm 癌であることが判明し， 腹会陰式直腸切断術を追加しさらに術後コベルト照射ま で行ったが，4年10カ月で局所再発にて死亡した症例で ある.この事実を見て, 著者たちは sm 癌は部分切除で 良いとは結論乙難い．この反論として根治手術は手術侵 襲が大きいからと良くいわれるが, 癌手術は癌を根治す ることが第 1 の目標であり，手術侵襲については癌腫の 高さにより肚門機能温存手術を行い, 万一直腸切断術に なってる小平・陣内たち ${ }^{16)}$ む述べているょうに，側方郭 清を含む拡大根治手術は必要ではない，著者たちの症例 6全例標準的手術を゙行っでり，その相対10生率は106 \%と良好で出った。後者 2)の意見の代表的なるのとし て，本シンポジウムに取上げられた松田たち ${ }^{17)}$ 症例を 見ると, 最長 4 年の follow up で13例中 2 例に再発を見 て却り，そのために 6 つの項目を設けて，これに低触し ない場合に局所切除を行らと述べている.しかし，著者 たちの直腸癌症例の再発期間を見ると， $5 \sim 6$ 年後に再 発するものがかなりあり，十分な follow up studyを行 ってから結論しないと危険を伴い，また，一般病院での 殓潦に混乱を招く恐れがあると思われる。部分切除が威 力を発揮するのはポリープ型病変である．まず，部分切 除を行い癌腫の深達度と病変の拡がりを診て (Excisonal biopsy), sm 癌以上であればただちに根治手術を追加す るのが，現在のところ安全であろう。

括約筋温存術式(とくに前方切除術括よび引き拔法)： 近年括約管温存術式の 適応抎大が 叫ばれているが, 根 治性を損わない積極的なものであれば，著者たちも賛成 である.しかし，前方切除術に执いては腫瑒の高さだけ を問題にせず，進行度，患者側の手術難易度，拉よび残 存結腸の血行状を考慮して適応を考兄るべきであるう。 しかし，引き拔法においては予後るとれ程良くなく，術 後の排便状態子決して好ましくない. ${ }^{5}$ ので, これらの症 例にはできるだけ，前方切除か重積法を行らべきである らと考えられた。

腹会陰式直腸切断術 : 教室では從来本法を優先的に行 ら傾向にあった（根治性が高いため）. 表11飞示す如く， これらの症例を Retrospective に見ると括約笳温存術 式の 適応範囲にあるものが多数見られた。すなわち， stage I, $5 \mathrm{~cm}$ 以上の症例が 24 例， $45.2 \%$, stage II, $6 \mathrm{~cm}$ 以上の症例が16例, $57.1 \%$, stage $\mathbb{I I}, 8 \mathrm{~cm}$ 以上 の症例が 7 例, $33.3 \%$ であり，これらの症例の多くのも のが，今後前方切除術または重積法が行われるものと期 待される，また，本法を施行するに当り，とくに注意す
ることは少なくとす肚門部癌に括いては, 拡大根治手術 が必要であるといらことである。

\section{9. おわりに}

1）教室における直腸肍門癌症例の各術式の適応を見 るために，症例を Retrospective に検討した.

2）術前の選択的下腸間膜動脈撮影の重要性を強調し た.

3）各術式別に相対生存率を検討したところ， $\mathrm{m} ・ \mathrm{sm}$ 癌症例群（ 5 生率： $85.2 \%, 10$ 生率：106.0\%）扰よび 前方切除術群 ( 5 生率：105.9\%，10生率：123.7\%) が 引き抜法群（ 5 生率： $65.2 \%, 10$ 生率 : $67.3 \%$ ) と腹会 陰式直腸切断術群（ 5 生率：64.6\%，10生率：58.3\%) に比して，著明に良好であった。すなわち， m・sm 癌 症例に打汸術式の選択と前方切除術の適応が正しいも のであったと考劣られる。

4）肛門緑よりの癌腫の高さによる特性を相対生存率 によって検討したところ, $3.9 \mathrm{~cm}$ 以下の群が 10 生率に 执いて，他群と有意差をるって悪く，この群の拡大根治 手術の重要性を痛感した.

5）前方切除術で良好な10生率が得られたので，その 癌腫の高さと進行度を検討したところ, Retrospective な前方切除術の適応は次の通りであった。

stage I $\cdot 5 \mathrm{~cm}$ 以上の 症例, stage II $6 \mathrm{~cm}$ 以上, stage III $\cdot 8 \mathrm{~cm}$ 以上, stage IV $\cdot 12 \mathrm{~cm}$ 以上の症例.

6）引き拔法の癌腫の高さと進行度の間には特別な関 係は見られず，癌再発には他因子の関与が示嘫された。

7）腹会陰式直腸切断術症例の進行度および癌腫の高 さの頻度と予後の関係を検討したところ，これらの症例 中には前方切除術または重積法が施行でさると考兄られ た症例が多数認められた。

8）再発形式を各術式別に検討したが，括約筋温存術 式の症例が少ないため, その差異については論じられな かった.

9）直腸肛門癌症例の術式選択の 基準について述べ た。

本論文の要旨は日本消化器外科学会第10回総会のシン ポジウムに怙いて発表した。

稿を䅂るにあたり，ご校閲をいたら゙いた東邦大学第 1 外科教室䉓谷寿彦教授化深甚なる謝意を表する。

\section{引用文献}

1) Goligher, J.C.: Surgery of the Anus Rectum and Colon, 3rd Ed., 777 Bailliere \& Tindall, London, 1975. 


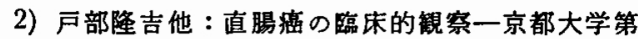

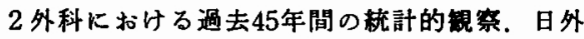
会誌, $76: 1081,1975$.

3) 安富正幸：直腸癌手術患者の遠隔成綪よりみた 手術々式の反省。日外会誌，75:1062，1974。

4) 北条慶一たち：根治切除不能例の対策。日消外 会誌, $7: 466,1974$.

5) 粕川用㼁：直腸癌における括約筋保存手術とそ の成精について。外科治療, $36: 69-84.1977$.

6) 大腸癌研究会編：大渴癌取报い規的. 15, 1976.

7) 栗原 登たち：癌の治瘁率の計算方法につい て。癌の臨床, 11：628一632, 1965.

8）小池淳夫他：コホート生存率表。厚生の指標, 23 (3) : 14-27, 1976.

9) Axtell, L.M.: Computing survival Rates for chronic Disease Patients, JAMA, 186: 1125 $1128,1963$.

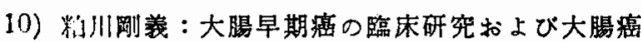
の病期分類についての考察．大腸肍門誌、26:
$371-379,1973$.

11) 粕川用義他：大腸早期癌の特異性. 大晹肛阴 誌, $29: 149,1976$.

12) 大森孛他 : 大腸早期癌の治療之予後. 大腸肛門 誌, 29 ： 467-468, 1976.

13）粕川剛義他：大腸癌取扱い規約に上る直腸癌の 予後と病期分類の検討. 第77回日外会総会号, 93, 1977.

14）鐏田重康他：特異な再発を示した大腸瘦症例に ついて。.大渴肛門誌, $29: 46-47,1976$.

15）粕川用㧴他：再発直晹癌の検討. 大腸肛門誌, $29: 47,1976$.

16) 小平 進，陣内伝之助：直腊找よび肚門癌の転 移と治療方針（シンボジム）における発言。 大腸肛門誌, $26: 54-55,1976$.

17) 松田好雄他：早期直腸癌に対する手術手技の選 択一とくに局所切除の意義と有用性について; 日消外会第10回総会号，11，1977. 